\title{
Rickets in the Tropics: not always nutritional
}

\author{
Poonam Singh, ${ }^{1}$ Gunvant Singh Eske, ${ }^{1}$ Mamta Dhaneria, ${ }^{1}$ Ashish Pathak ${ }^{1,2,3}$
}

1 Department of Pediatrics, RD Gardi Medical College, Ujjain, Madhya Pradesh, India

${ }^{2}$ Department of Public Health Sciences, Global Health (IHCAR), Stockholm, Solna, Sweden

${ }^{3}$ Department of Women and Children's Health, International Maternal and Child Health Unit, Uppsala University, Uppsala, Sweden

\section{Correspondence to} Dr Ashish Pathak: drashishp@rediffmail.com

\section{DESCRIPTION}

Vitamin D-dependent rickets type I

A 6-year-old girl belonging to the lower socioeconomic class of a Muslim community, product of consanguineous marriage presented in the paediatric outpatient department with a history of progressive bowing of limbs, recurrent chest infections requiring hospitalisations in the past and failure to thrive. Calorie and protein consumption was just one-third of the requirement. Family history of similar problems was present in the mother. The mother had frank rickets beginning at the age of 1 and progressively increasing with age. The mother was treated at a private clinic for her disease with 1,25-dihydroxycholecalciferol (Calcitriol). A clinical examination revealed florid manifestations of rickets (figure1 A-D). Investigations showed near normal 25 -hydroxy vitamin $\mathrm{D}$ and a low concentration of 1,25-dihydroxyvitamin D supporting the diagnosis of vitamin D-dependent rickets type-I
(VDDR-I; table 1 and figures 2 and 3). VDDR-I also called as pseudo-vitamin D deficiency rickets, is an autosomal recessive disorder occurring due to impaired activity of renal 25-hydroxyvitamin D 1 $\alpha$-hydroxylase associated with raised 25-hydroxyvitamin D concentrations and markedly low to undetectable concentrations of 1,25-dihydroxyvitamin D. ${ }^{1}$

\section{Vitamin D-dependent rickets type-II in siblings}

Two male siblings of age 9 and 2.5 years, respectively, belonging to a poor Hindu family presented with progressive deformity of the limbs, not gaining height, hairfall beyond the neonatal period preceded by folliculitis and premature falling of teeth. Younger sibling had painful lower limbs and did not start walking. On examination, all the growth parametres were below third centile. Both the children had classical manifestations of severe rickets along with peculiar features (a)

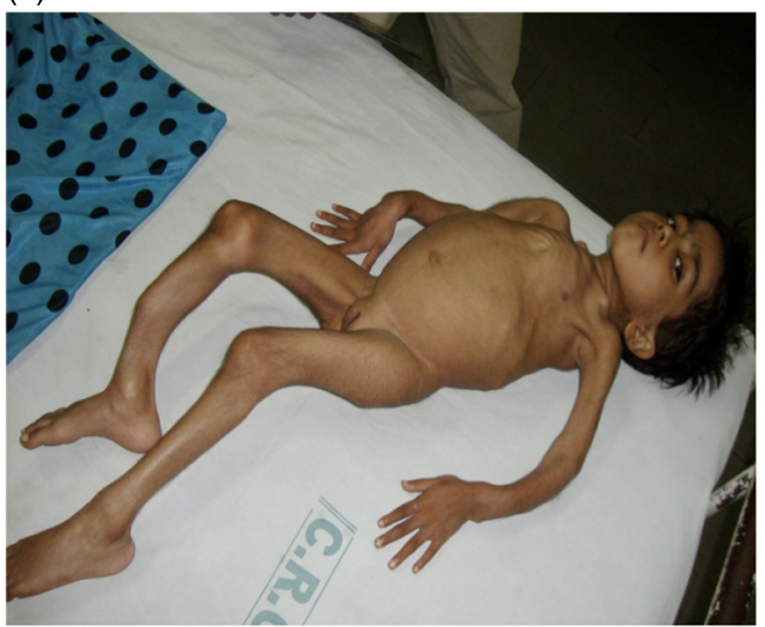

(c)

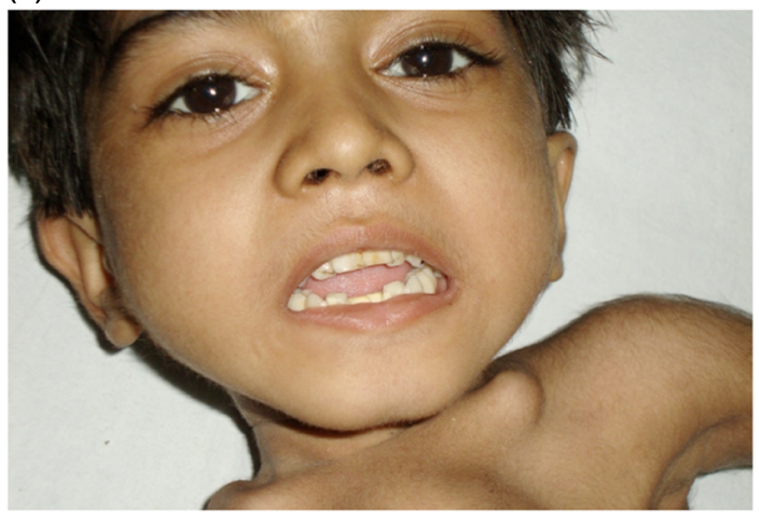

(b)

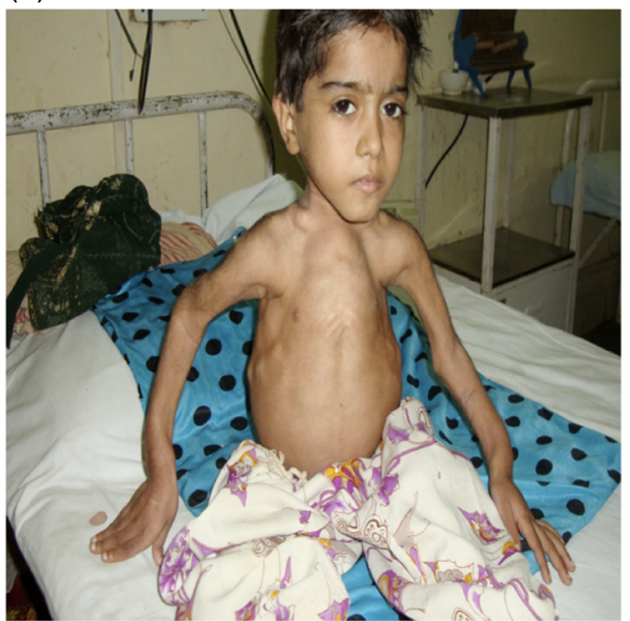

(d)

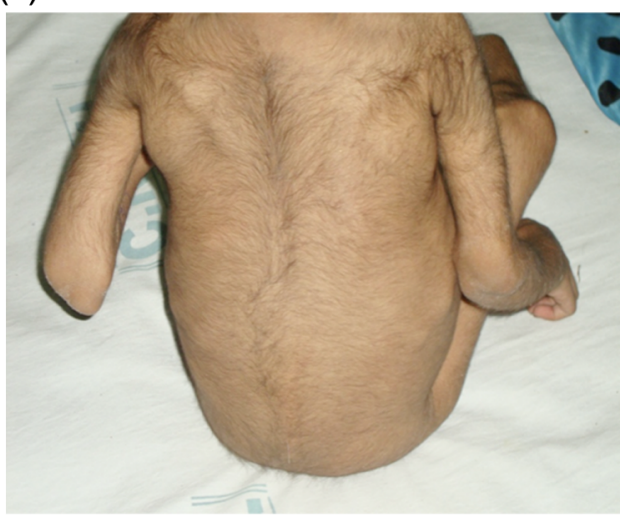

To cite: Singh P, Eske GS, Dhaneria $\mathrm{M}$, et al. BMJ Case Rep Published online:

[please include Day Month Year] doi:10.1136/bcr-2013009786
Figure 1 (A) Features of florid rickets: marked bowing of forearms and legs. (B) Features of florid rickets: narrow bell-shaped pigeon chest with rachitic rosary and marked bowing of forearms. (C) Yellow enamel changes and (D) scoliosis. 
Table 1 Investigations of three cases of pathological rickets

\begin{tabular}{lllc}
\hline Investigations & Normal & VDDR-I & VDDR-II (sibling1) \\
\hline S.calcium (mmol/L) & $2.25-2.75$ & 1.52 & 2.07 \\
S.phosphorus (mmol/L) & $1.13-1.45$ & 0.58 & 1.19 \\
Alkaline phosphatase (U/L) & 300 & 1001 & 1457 \\
Parathormone $(\mathrm{pg} / \mathrm{mL})$ & $11.1-79.5$ & 98.8 & 548 \\
$25(\mathrm{OH})$ vitamin D $(\mu \mathrm{g} / \mathrm{L})$ & 30 & 29.6 & - \\
$1,25(\mathrm{OH})_{2}$ vitamin D (nmol/L) & $47.04-130.32$ & 21.6 & - \\
\hline
\end{tabular}

(a)

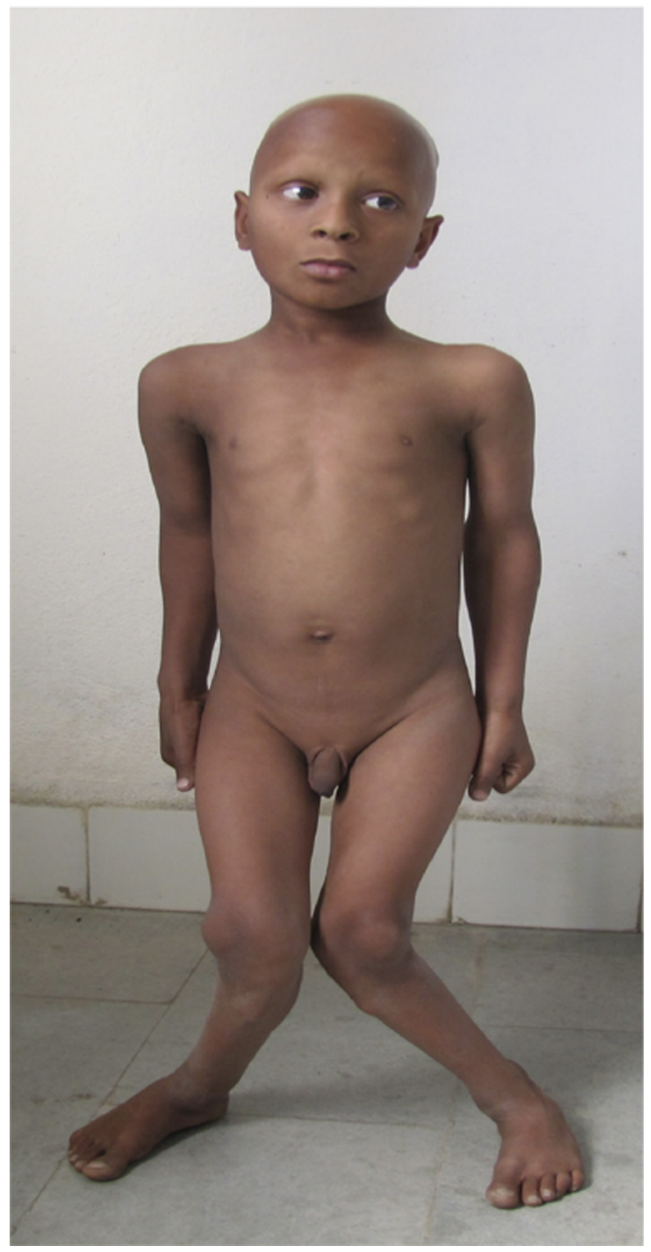

(b)

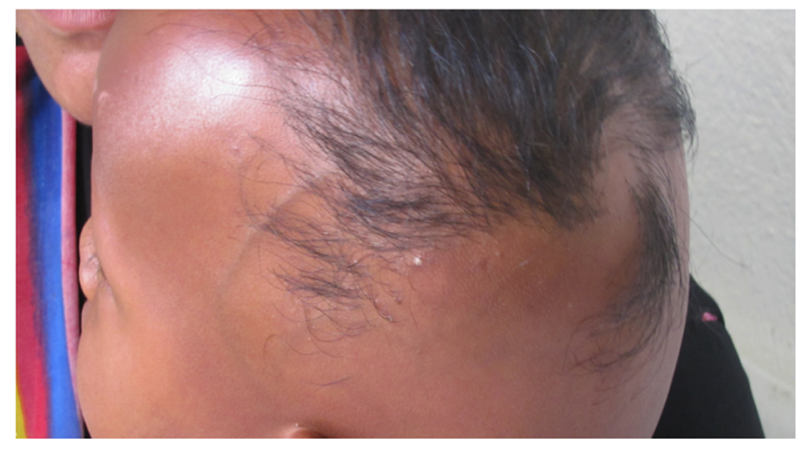

(c)

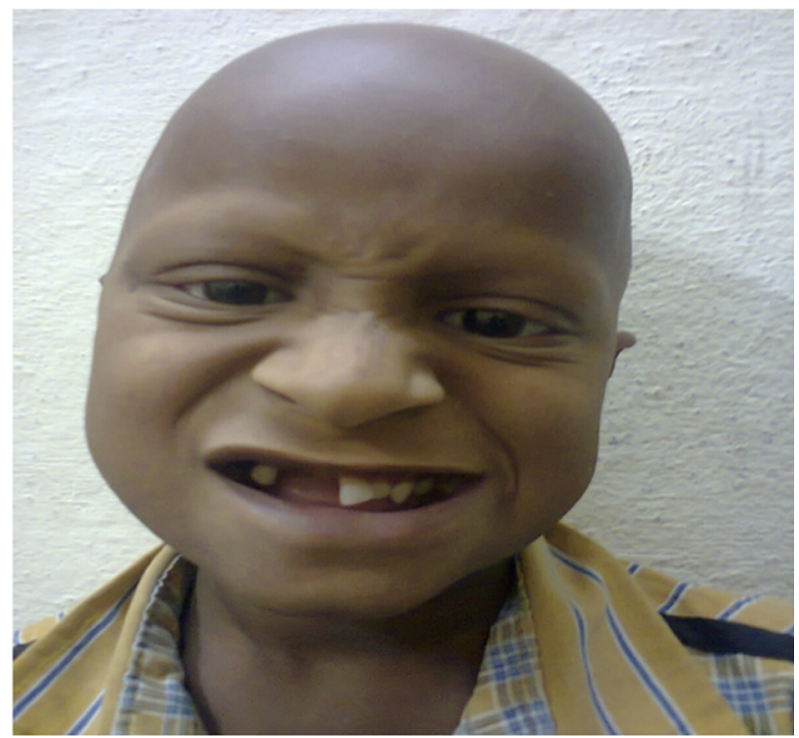

Figure 2 (A) Vitamin D-dependent rickets type II (VDDR-II) sibling 1 showing genu valgum and alopecia totalis. (B) VDDR-II sibling 2 showing folliculitis (precedes hair loss) and alopecia. (C) VDDR-II sibling 1 showing premature loss of tooth.

of VDDR-II in the form of alopecia totalis, epidermal cyst and premature falling of teeth ${ }^{2}{ }^{3}$ (figure $2 \mathrm{~A}-\mathrm{C}$ ). Owing to the financial constraints of the patients' family, 1,25-dihydroxyvitamin $\mathrm{D}$ and parathyroid hormone could not be performed but alopecia and premature falling of teeth were the strong pointers to this rare diagnosis. ${ }^{2}{ }^{3}$ Investigations are shown in table 1. VDDR-II also known as hereditary 1,25-dihydroxyvitamin D resistant rickets, is a rare autosomal recessive disease that arises as a result of mutations in the gene encoding the vitamin D receptor. It usually presents with early onset severe rickets and alopecia with elevated circulating levels of 1,25-dihydroxyvitamin D3. ${ }^{4}$ 


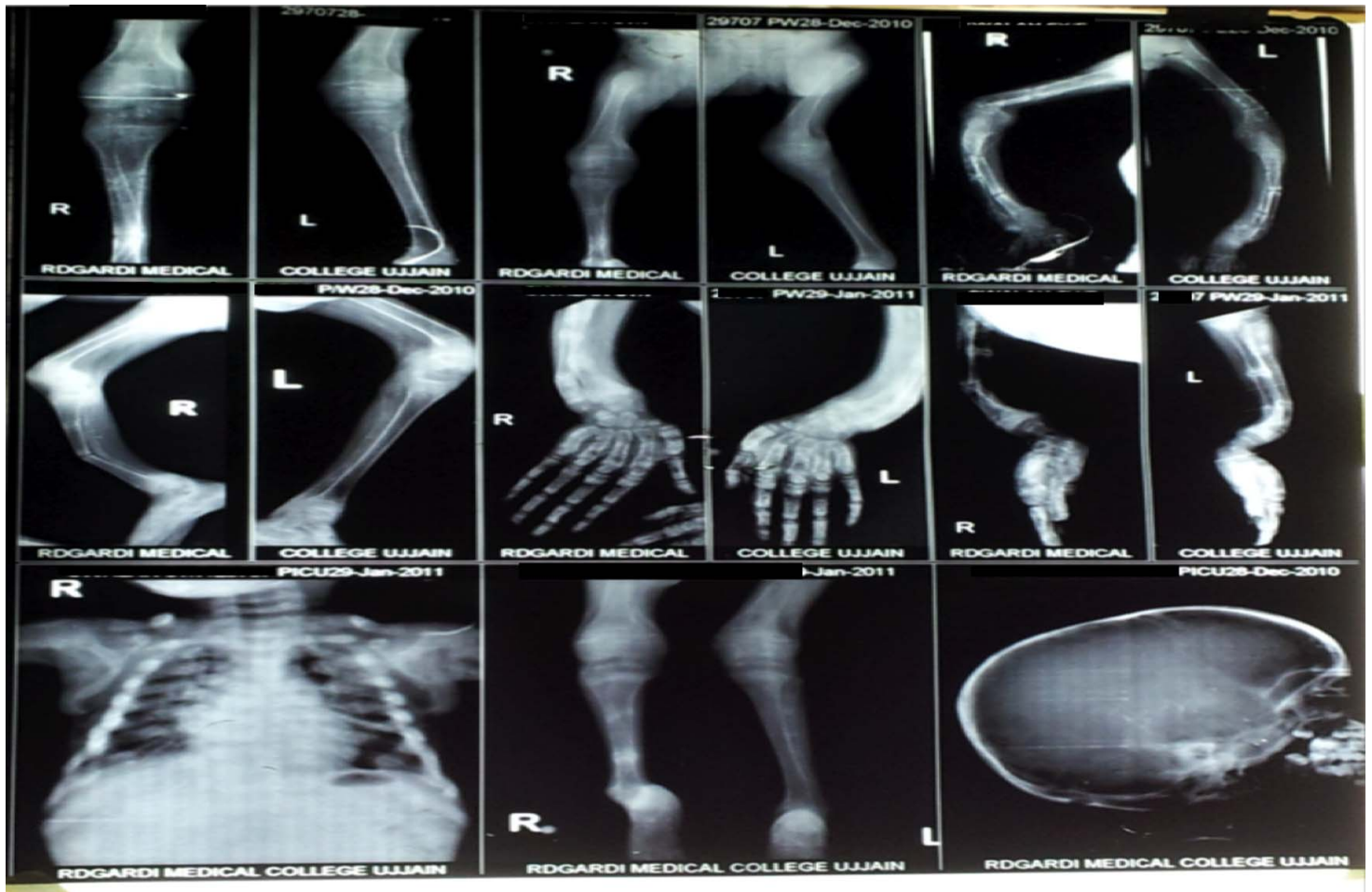

Figure 3 Radiological features of vitamin D-dependent rickets type I: bowing, cupping, fraying and widening of the metaphyses, severe osteopenia and pathological fractures.

\section{Learning points}

- All cases of rickets are not nutritional in origin even in tropical countries.

- Genetic causes should be strongly considered if patient presents beyond 2 years of age with severe rickets, pathological fractures, positive family history and failure to respond to vitamin $\mathrm{D}$.

- Alopecia and premature falling of teeth are important clinical pointers to vitamin D-dependent rickets type II.

Contributors PS, GSE and AP collected the clinical details and photographs of the patient report. PS performed the literature review and drafted the manuscript. MD and $\mathrm{AP}$ verified the diagnosis and other scientific facts. All the authors were responsible for clinical follow-up of the case. All authors read and approved the final version of the manuscript.

Competing interests None.

Patient consent Obtained.

Provenance and peer review Not commissioned; externally peer reviewed.

\section{REFERENCES}

1 St-Arnaud R, Messerlian S, Moir JM, et al. The 25 hydroxyvitamin D 1-alpha hydroxylase gene maps to the pseudovitamin D-deficiency rickets (PDDR) disease locus. J Bone Miner Res 1997;12:1553-9.

2 Malloy PJ, Feldman D. Genetic disorders and defects in vitamin d action. Endocrinol Metab Clin North Am 2010;39:333-46.

3 Malloy PJ, Feldman D. The role of vitamin D receptor mutations in the development of alopecia. Mol Cell Endocrinol 2011;347:90-6.

4 Tokita A, Hisada K, Nishizawa K. Bone disease with vitamin D receptor abnormality. Nippon Rinsho 2002;60:385-90.

Copyright 2013 BMJ Publishing Group. All rights reserved. For permission to reuse any of this content visit http://group.bmi.com/group/rights-licensing/permissions.

BMJ Case Report Fellows may re-use this article for personal use and teaching without any further permission.

Become a Fellow of BMJ Case Reports today and you can:

- Submit as many cases as you like

- Enjoy fast sympathetic peer review and rapid publication of accepted articles

- Access all the published articles

- Re-use any of the published material for personal use and teaching without further permission

For information on Institutional Fellowships contact consortiasales@bmjgroup.com

Visit casereports.bmj.com for more articles like this and to become a Fellow 